\title{
Karakteristik Pengunjung Obyek Wisata Di Kawasan Danau Rawa Pening (Kasus Kecamatan Banyubiru, Kabupaten Semarang, Jawa Tengah)
}

\author{
Deasyka Milna Syahputri ${ }^{1}$, Firda Nur Fatta ${ }^{1}$, Aditya Nurrahma ${ }^{1}$, Kirana Amurwa Kusuma ${ }^{1}$, \\ Rifa'i Ichsanuddin ${ }^{1}$, Sri Wisudaryono ${ }^{1}$, Marcelo Salas ${ }^{1}$, Yunus Aris Wibowo ${ }^{1}$ \\ Program Studi Pendidikan Geografi, Fakultas Keguruan dan Ilmu Pendidikan, \\ Universitas Muhammadiyah Surakarta, Jawa Tengah 57162 \\ E-mail: deasykamilna07@gmail.com
}

Dikirim : 19 Juni 2019

Diterima: 30 Juni 2019

\begin{abstract}
Abstrak: Dalam rangka memanfaatkan sumberdaya alam sebagai pengembangan ekowisata berbasis masyarakat, perlu disusun rencana yang lebih menyeluruh, baik penyediaan sarana prasarana pendukung pariwisata, bentuk kerja sama antar pemerintah, pihak swasta dan pihak masyarakat dengan memperhatikan potensi-potensi yang ada. Sehingga kawasan tersebut dapat menjadi daerah tujuan wisata yang menarik. Tujuan dari penelitian ini adalah untuk mengetahui karakteristik wisatawan di Danau Rawa Pening. Metode penelitian ini menggunakan metode deskriptif kuantitatif, populasi dalam penelitian ini adalah pengunjung obyek wisata di sekitar Danau Rawa Pening, kemudian digunakan teknik sampling dan menghasilkan 345 responden penelitian. Hasil penelitian menunjukan karakteristik wisatawan pada obyek wisata di kawasan Rawa Pening. Adanya pengetahuan mengenai karakteristik tersebut dapat memaksimalkan upaya pengemasan dan perwujudan sarana sebagai faktor pendukung yang meliputi jasa transportasi, akomodasi, restoran, pusat-pusat perbelanjaan, jaringan perbankan, fasilitas keamanan, dan fasilitas umum lain yang disediakan oleh para pemangku kepentingan pariwisata sehingga mendukung adanya kegiatan pariwisata bagi wisatawan.
\end{abstract}

Kata Kunci: Ekowisata, Sumberdaya Alam, Pemanfaatan

\begin{abstract}
More comprehensive plan is needed in order to utilize natural resources as ecotourism development in the perspective of tourism society based, both in the provision of supporting facilities for tourism, the government cooperations and the private sector, also the society based on its potencial. So that the area became an attractive tourist destination. This research aims to find out the characteristics of tourists at Rawa Pening Lake. This research used descriptive quantitative method, the population of this study were the visitors of tourism objects around Rawa Pening, by using a sampling technique, produced 345 research respondents. The results show the characteristics of tourists on tourism objects in the Rawa Pening area. The knowledge of these characteristics can maximize the packaging and embodiment of facilities as supporting factors, include transportation services, accommodation, restaurants, shopping centers, networks banking, security facilities, and the other public facilities provided by tourism stakeholders to support all the tourism activities.
\end{abstract}

Keyword : Ecotourism, Natural Resources, Utilization

\section{Pendahuluan}

Sumberdaya alam yang dimiliki oleh Indonesia sangatlah besar, ekosistem perairan darat merupakan salah satu sumberdaya yang sangat dominan contohnya danau. Menurut Anugerah Nontji (2016), Indonesia memiliki hampir 840 danau yang menjadi sumber kehidupan baik manusia, hewan dan tumbuhan disekitarnya. Hal itu karena danau menyediakan sumberdaya alam yang produktif baik sebagai sumber air baku minum, kebutuhan rumah tangga, sumber protein, mineral, energi, transportasi dan sebagai obyek wisata.

Danau Rawa Pening secara geografis terletak di antara jalan Semarang-SalatigaSurakarta dan jalan kabupaten antara Semarang dan Ambarawa. Rawa Pening terdapat pada 
cekungan terendah lereng Gunung Merbabu, Gunung Telomoyo, dan Gunung Ungaran yang meliputi wilayah Kecamatan Ambarawa, Bawen, Tuntang dan Banyubiru. Sedangkan secara astronomis terletak pada koordinat $7^{\circ} 04^{\prime} 00^{\prime \prime}$ - $7^{\circ} 30^{\prime} 00^{\prime \prime}$ LS dan $110^{\circ} 24^{\prime} 46^{\prime \prime}-110^{\circ} 49^{\prime} 06^{\prime \prime}$ BT. Danau Rawa pening berada pada ketinggian 450 - 470 meter di atas permukaan air laut. Kapasitas tampungan air sebesar $65.000 .000 \mathrm{~m}^{3}$ pada elevasi $\pm 436,90^{\circ}$ (Whitten et al, 1996). Kondisi hidrologi pada danau Rawa Pening meliputi kondisi permukaan air dan airtanah. Hal itu dipengaruhi oleh kondisi topografi, vegetasi dan jumlah curah hujan. Selain itu perairan Danau Rawa Pening memiliki keanekaragaman hayati yang cukup tinggi (Setyono, 2014:3).

Rawa Pening juga memiliki pemandangan alam yang merupakan perpaduan hamparan perairan dengan latar belakang gunung merupakan daya tarik tersendiri. Hal ini menunjukan adanya sumberdaya alam yang dimiliki Rawa Pening memiliki potensi tinggi terhadap sektor pariwisata. Pariwisata sendiri merupakan suatu fenomena yang menghasilkan pertumbuhan ekonomi. Dalam perekonomian suatu negara, bila dikembangkan secara terencana dan terpadu, peran pariwisata akan melebihi sektor migas serta industri lainnya (Yoeti, 2008:1). Kawasan Danau Rawa Pening merupakan salah satu tempat yang memiliki potensi wisata tinggi, ditinjau dari beragam atraksi wisata, baik secara alami maupun buatan hal ini menjadikan Danau Rawa Pening memiliki daya tarik dengan potensi lokal. Potensi - potensi yang ada tidak dapat dimanfaatkan oleh masyarakat secara efektif jika tidak ada pengelolaan dan pengembangan yang baik. Sebaliknya jika potensi dapat dimanfaatkan secara maksimal, dapat menciptakan peluang terutama dalam bidang ekowisata. Ekowisata yang dilaksanakan akan berperan sebagai penciptaan lapangan kerja dan lapangan usaha. Kegiatan tersebut akan menambah pendapatan yang akan menunjang kegiatan ekonomi.

Pengembangan pariwisata menjadi kegiatan ekonomi dan industri yang melibatkan banyak individu, perusahaan, organisasi dan asosiasi. Ini penting secara ekonomi karena menyediakan sumber pendapatan dan lapangan kerja, membawa perbaikan infrastruktur dan membantu pembangunan daerah (Negi, 1990). Hal tersebut selain berguna untuk menjadi pusat daya tarik melainkan juga untuk menjanjikan kepuasan pengunjung pada wisata di Danau Rawa Pening. Dalam rangka mencapai pengembangan optimal obyek wisata pada kawasan Rawa Pening, maka diadakan penelitian untuk mengetahui karakteristik wisatawan di kawasan Rawa Pening yang hasilnya diharapkan dapat dijadikan dasar pengembangan.

\section{Metode Penelitian}

Jenis penelitian ini menggunakan metode deskriptif kuantitatif. Sumber utama yang menjadi data penelitian berada di lokasi Kecamatan Banyubiru. Penelitian ini adalah obyekobyek wisata yang berada di sekitar Rawa Pening. Waktu pelaksanaan penelitian ini dilaksanakan mulai Bulan Februari pembuatan hingga Bulan Mei.

\section{Pengumpulan Data}

Populasi dalam penelitian ini adalah pengunjung obyek wisata di Kawasan Danau Rawa Pening. Aktivitas yang diteliti dalam penelitian ini adalah karakteristik wisatawan. Pengambilan sampel dilakukan dengan teknik incidental sampling. Teknik ini dapat memilih sampel berdasarkan orang yang paling mudah ditemui di tempat penelitian. Sampel yang digunakan dalam penelitian ini menghasilkan 345 responden penelitian. Satuan analisis yang digunakan pada penelitian ini adalah jenis obyek wisata, yaitu wisata alami dan wisata buatan.

\section{Analisis Data}

Teknik pengambilan data melalui kuesioner sumber berasal dari pengunjung. Analisis data dengan menggunakan data kuesioner yang sudah terkumpulkan kemudian diolah pada 
perangkat lunak microsoft excel dan Sistem Informasi Geografis (SIG) untuk mengklasifikasikan dan memutuskan kesimpulan akhir dan rekomendasi.

\section{Hasil Penelitian dan Pembahasan \\ Obyek Wisata Alami Pemandian Muncul Tinjauan Atraksi, Amenitas, Aksesibilitas}

Pemandian muncul terletak di Dusun Muncul, Desa Rowoboni, Kecamatan Banyubiru, Kabupaten Semarang, Jawa Tengah. Pemandian Muncul dianggap sangat strategis karena terletak berdekatan dengan Danau Rawa Pening. Pemandian Air Muncul adalah pemandian alami dengan sumber air yang berasal dari mata air di dasar kolam. Biaya retribusi Rp 7.000,00 untuk dapat menikmati berbagai fasilitas yang sudah tersedia di Pemandian Air Muncul. Fasilitas yang ditawarkan yaitu, kolam pemandian berukuran 20×40 meter, area parkir , mushola, kamar mandi / MCK, penginapan, tempat makan, penyewaan pelampung. Di sekitar pemandian air muncul belum terdapat hotel dengan kualitas bagus, baru tersedia penginapan sederhana.

Kondisi jalan menuju lokasi pemandian cukup baik dengan kondisi jalan beraspal meskipun tidak terlalu lebar. Petunjuk arah lokasi objek wisata belum ditemukan disepanjang jalan menuju lokasi tersebut, tetapi petunjuk lokasi bisa diperoleh dari aplikasi Google Maps. Transportasi umum yang tersedia adalah angkutan umum yaitu angkutan kota yang juga beroperasi hingga Kecamatan Banyubiru. Pemandian air muncul juga menyajikan beberapa hiburan berupa festival musik di hari Minggu dan ritual Padusan yang secara rutin dilaksanakan satu tahun sekali menjelang bulan Ramadhan. Acara tersebut sangat menarik bagi wisatawan, namun sebagian responden yang berasal dari luar Kabupaten Semarang tidak mengetahui informasi pelaksanaan acara tersebut karena kurangnya publikasi dari penyelenggara. Kekurangan lainnya adalah minimnya peedagang cindera mata yang berkaitan dengan Pemandian Air Muncul sehingga pengunjung kesulitan mendapatkan oleh-oleh khas sebagai kenang-kenangan.

\section{Karakteristik Pengunjung \\ Usia Pengunjung}

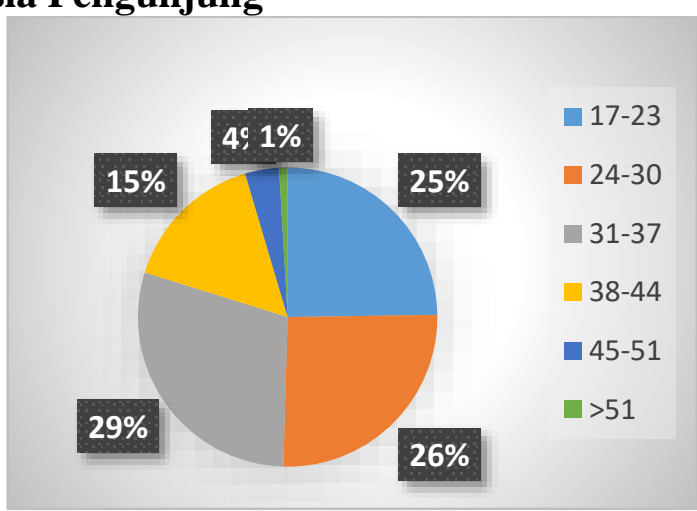

Gambar 1. Persentase Usia Pengunjung Pemandian Muncul

Tingkat signifikansi jumlah kunjungan Pemandian Muncul salah satunya dipengaruhi oleh faktor usia. Hasil observasi menunjukkan bahwa rentang usia pengunjung Pemandian Air Muncul antara 31-37 tahun (Gambar 1). Hal itu dikarenakan sasaran utama Pemandian Air Muncul adalah pengunjung usia dewasa, sedangkan pengunjung usia remaja dan anak-anak cenderung memilih Pemandian Muncul Park yang terletak di sebelah Pemandian Air Muncul dengan berbagai fasilitas menarik bagi anak-anak. Persentase pengunjung terbesar kedua yaitu 26\% pada rentang usia 24-30 tahun dan yang ketiga 25\% dengan rentang usia 17-23 tahun, hal itu mengindikasikan bahwa Pemandian Air Muncul juga dikunjungi oleh pengunjung remaja. 


\section{Jenis Kelamin}

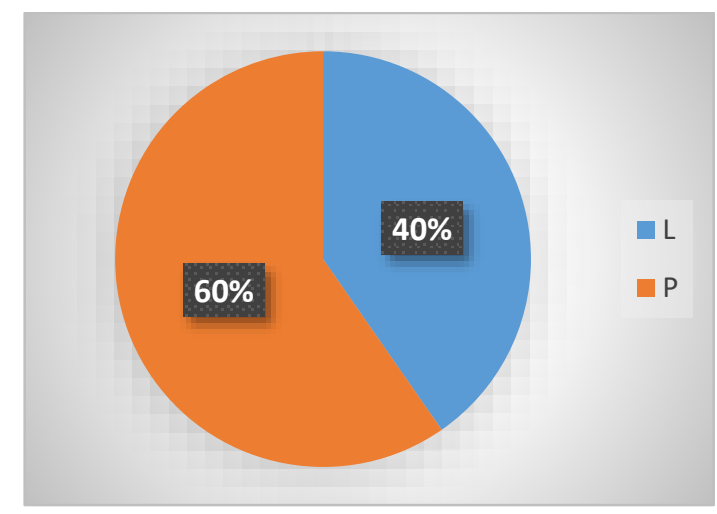

Gambar 2. Persentase Jenis Kelamin Pengunjung Muncul

Hasil observasi menunjukkan bahwa pengunjung Pemandian Muncul didominasi oleh perempuan dengan persentase $60 \%$ dibandingkan laki-laki dengan persentase $40 \%$ (Gambar 2). Hal itu merupakan indikator bahwa pengunjung perempuan di Pemandian Air Muncul lebih banyak dibandingkan dengan laki-laki karenakan kebanyakan perempuan lebih mudah merasa jenuh dengan suatu aktivitas sehari-harinya dan ingin melepas dari kejenuhan mereka melakukan kunjungan ke tempat wisata.

\section{Pendidikan Terakhir}

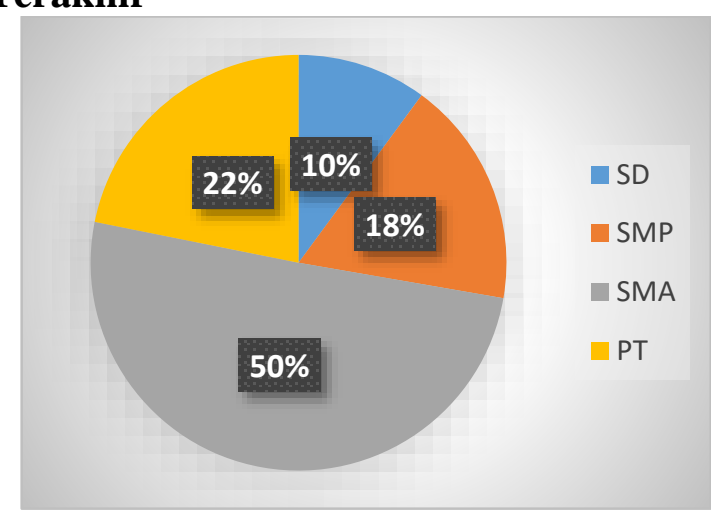

Gambar 3. Persentase Pendidikan Terakhir Pengunjung Pemandian Muncul

Dalam pengembangan manusia, unsur pendidikan dapat dijadikan sebagai salah satu indikator taraf kesejahteraan masyarakat, dengan asumsi bahwa tingkat pendidikan yang baik (tinggi) dapat memberikan jaminan seseorang meningkatkan kondisi perekonomiannya. Tingkat pendidikan terakhir pengunjung Pemandian Air Muncul didominasi jenjang SMA dengan presentase 50\%. Presentase tinggi kedua yaitu $22 \%$ yaitu pada jenjang Perguruan Tinggi (PT) (Gambar.3). Pendidikan terakhir akan mempengaruhi oleh jenis pekerjaan dan jenis pekerjaan akan berpengaruh terhadap tingkat penghasilan yang berimplikasi terhadap pemenuhan kebutuhan tersier seperti pariwisata.

\section{Pekerjaan}




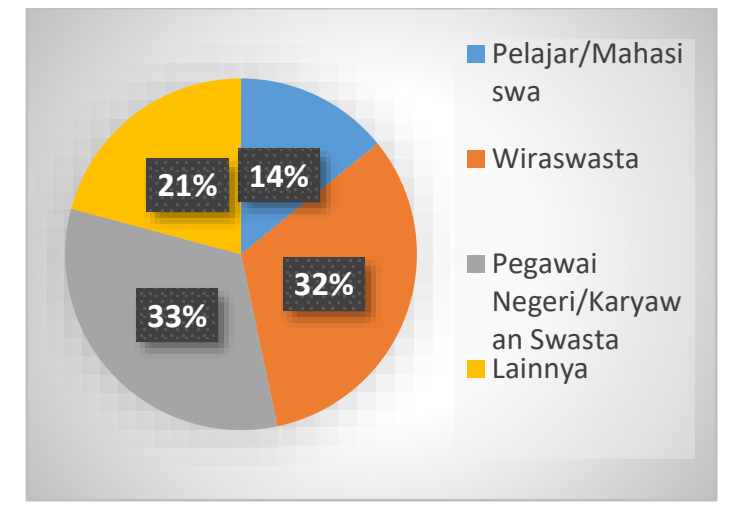

Gambar 4. Persentase Pekerjaan Obyek Wisata Pemandian Muncul

Dominasi pekerjaan pengunjung Pemandian Muncul yaitu pegawai negeri/karyawan swasta dengan presentase 33\% (Gambar 4) rata-rata berpenghasilan 1-3 jt (Gambar 5) obyek wisata muncul lama banyak diminati oleh pengunjung usia dewasa sehingga sangat berpengaruh sekali terhadap pekerjaan, pegawai negeri memang memiliki kelebihan dalam penghasilan dibandingkan mahasiswa/pelajar dimana pengunjung yang memiliki pekerjaan pegawai negeri/kayawan dapat sudah mengalokasikan pengasilannya untuk kebutuhan tersier seperti berwisata.

\section{Penghasilan}

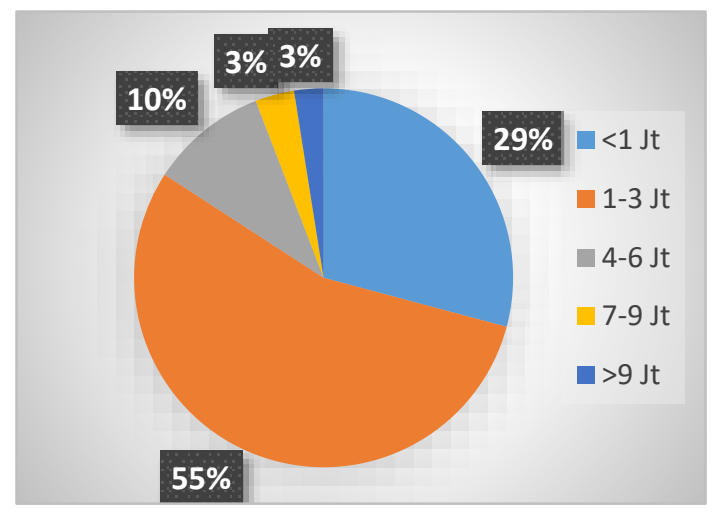

Gambar 5. Persentase Penghasilan Pengujung Muncul

Pegawai negeri/karyawan memberikan pengaruh pada penghasilan pengunjung wisata Pemandian Muncul dengan diagram hasil penelitian yang menunjukkan 55\% (Gambar 5) berpenghasilan 1-3 jt dalam kurun waktu satu bulan, pendapatan tetap pegawai negeri/karyawan dapat memberikan kemudahan akses dalam berwisata kepada pengunjung karena sedikit kemungkinan terdapat kendala keuangan. Terlebih untuk harga tiket masuk wisata Pemandian Muncul lama relatif terjangkau semua kalangan. Pelajar/mahasiswa harus dapat menyisihkan uang mereka untuk berwisata. 


\section{Waktu Kunjung}

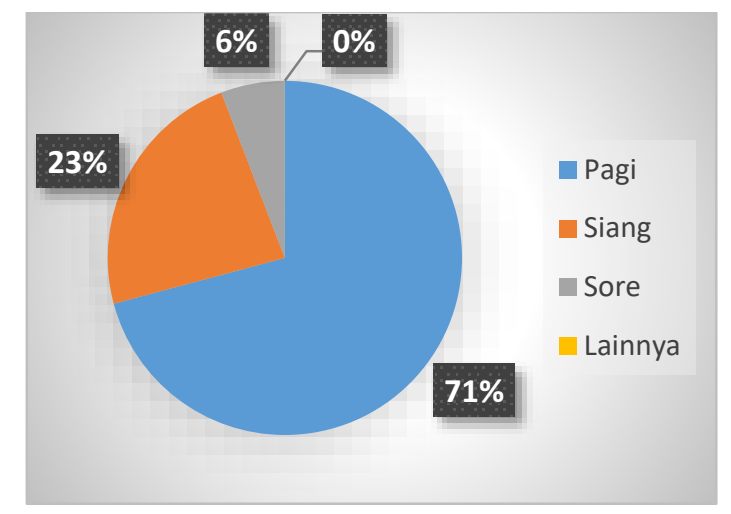

Gambar 6. Persentase Waktu Kunjung Pemandian Muncul

Waktu kunjungan yang sering dipilih pengunjung obyek wisata Pemandian Muncul yaitu pagi dengan miliki persentase $71 \%$ (Gambar 6) dibandingkan siang dengan presentase $23 \%$ dan sore dengan presentase $6 \%$. Mayoritas pengunjung lebih memilih pagi dikarenakan suasana udara masih sangat segar dan sejuk, namun tidak sedikit pengunjung juga memilih siang hari maupun sore hari mungkin karena waktu senggang pengunjung setelah beraktivitas pada siang hari, terkecuali apabila hari libur dan hari minggu tentu lebih di dominasi waktu pagi hari.

\section{Gumuk Reco}

\section{Tinjauan Atraksi, Amenitas, Aksesibilitas}

Wisata alam Gumuk Reco terletak di Desa Sepakung. lokasi ini sangat cocok untuk liburan dengan rekan maupun bersama keluarga, karena konsep wisatanya sangat bagus. Lokasi yang terletak di dataran tinggi mempunyai temperatur udara yang sangat sejuk. Daya tarik obyek wisata adalah sebagai tempat wisata untuk refresing dan berfoto dengan lokasi yang menarik. seperti foto ayunan cinta, gardu pandang, foto diatas pohon, sarang burung. Harga tiket Rp 5.000,00 untuk setiap hari kerja maupun hari libur. Pemandian Muncul buka mulai pukul 07.00 - 18.00 setiap hari.

Fasilitas yang tersedia mulai dari gazebo, toilet, wifi spot, tempat makan, mushola semua sudah ada dan terawat dengan baik. Namun demikian, belum terdapat penginapan atau hotel di sekitarnya. Obyek wisata tersebut dapat ditempuh kurang lebih 35 menit dengan jarak $10 \mathrm{~km}$ dari pusat Kota Ungaran. Jalan menuju area lokasi ini relatif sempit dan terjal. Transportasi umum menuju tempat wisata tersebut yang tersedia adalah ojek motor dan angkutan umum juga jarang, sehingga pengunjung memilih menggunakan kendaraan pribadi.

\section{Karakteristik Pengunjung Usia Pengunjung}




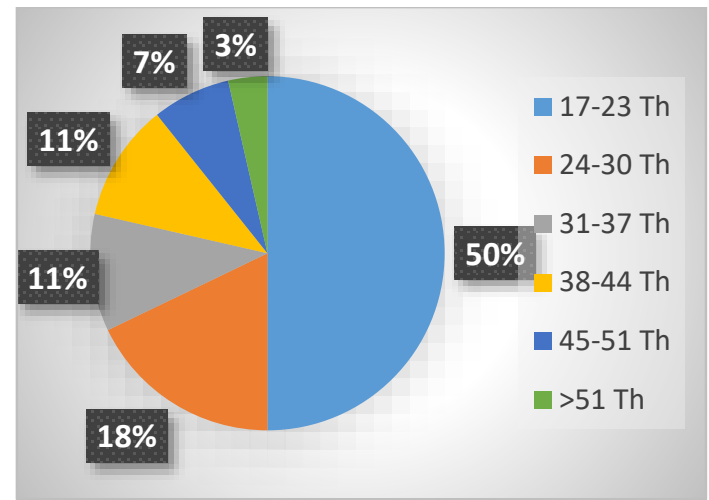

Gambar 7. Persentase Usia Pengunjung Gumuk Reco

Usia pengunjung obyek wisata Gumuk Reco dengan presentase 50\% didominasi rentang usia 17 - 23 tahun (Gambar 7). Hal itu menandakan obyek wisata tersebut sangat diminati oleh remaja, terlebih banyak sekali spot-spot yang membuat remaja tertarik untuk berfoto dan mengunggah ke sosial media sehingga dari aktivitas pengunjung tersebut dapat menunjang promosi pemasaran obyek.

\section{Jenis Kelamin}

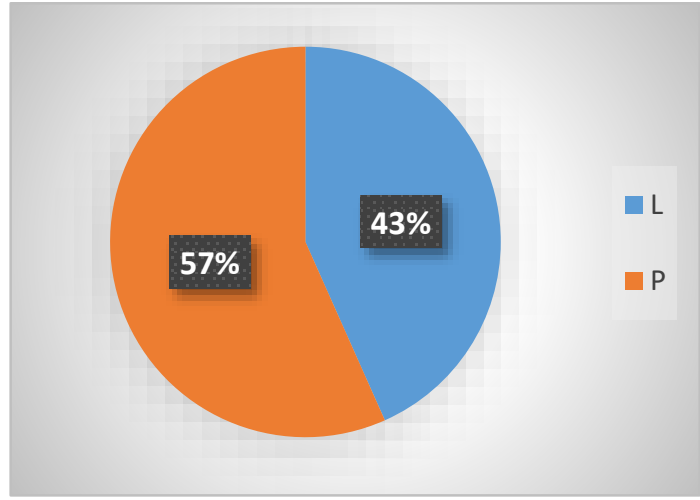

Gambar 8. Persentase Jenis Kelamin Pengunjung Gumuk Reco

Pengunjung objek wisata Gumuk Reco rata-rata berjenis kelamin perempuan terbukti dari hasil observasi menunjukkan 57\% (Gambar 8). Berbeda dengan pengunjung berjenis kelamin laki-laki dengan presentase 43\%. Hal itu karena perempuan memiliki sifat dan eksistensi lebih tinggi jika dibandingkan laki-laki.

\section{Pendidikan Terakhir}

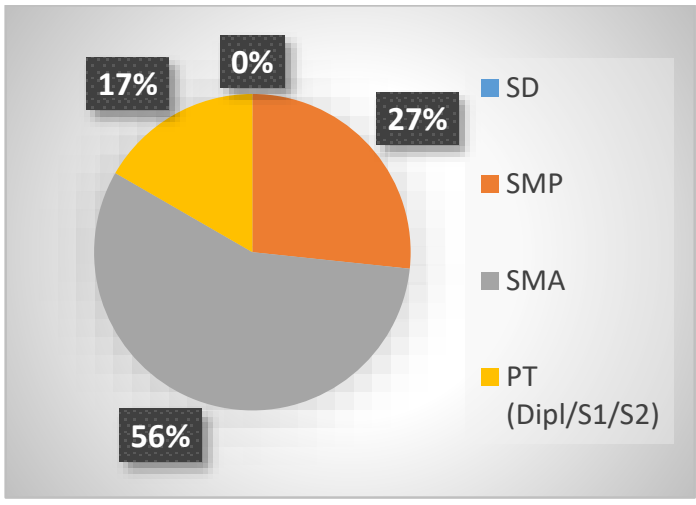

Gambar 9. Persentase Pendidikan Terakhir Pengunjung Gumuk Reco 
Pendidikan terakhir responden yang berkunjung ke Gumuk Reco didominasi oleh usia siswa jenjang Sekolah Menengah Atas (SMA) dengan persentase $56 \%$ (Gambar 9). Faktor utama yang sangat berpengaruh yaitu harga retribusi yang terjangkau yaitu Rp 5.000,00 hal lain menjadi ketertarikan pengunjung terhadap obyek wisata dikarenakan terdapat beberapa wahana yang menarik untuk dicoba, seperti ayunan langit yang bagus untuk diambil gambar dan diunggah ke media sosial.

\section{Pekerjaan}

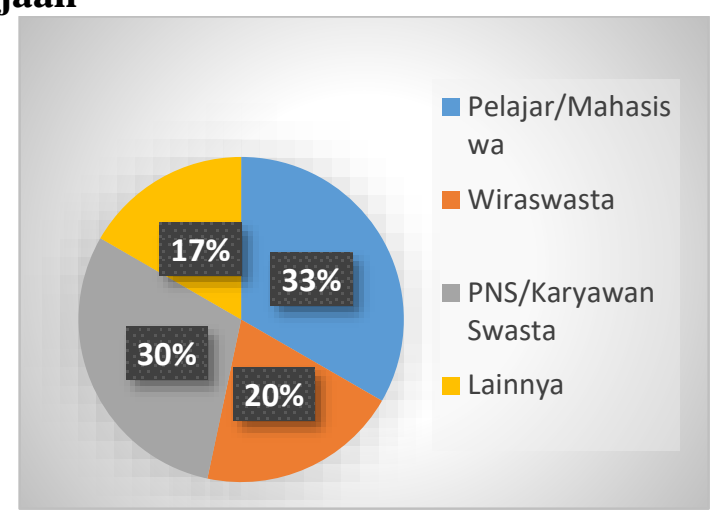

Gambar 10. Persentase Pekerjaan Pengunjung Gumuk Reco

Pengunjung Gumuk Reco didominasi oleh pelajar atau mahasiswa dengan persentase 33\% karena Gumuk Reco merupakan tempat wisata yang sangat cocok untuk anak muda dan biaya yang masih tergolong murah (Gambar 10). Selain pelajar atau mahasiswa ada juga pengunjung PNS/Karyawan Swasta yang berlibur dengan alasan mencari tempat yang sejuk dan pemandangan alam yang masih sangat alami.

\section{Penghasilan}

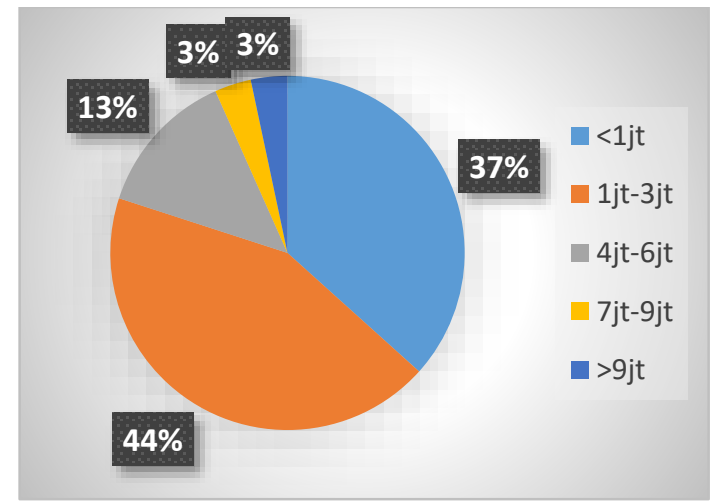

Gambar 11. Persentase Penghasilan Pengunjung Gumuk Reco

Penghasilan yang didominasi PNS/ Karyawan Swasta memberikan pengaruh pada penghasilan pengunjung obyek wisata dengan diagram menunjukkan $44 \%$ berpenghasilan 1.000.000,00-3.000.000,00 perbulan, dimana harga tiket masuk Gumuk Reco masih tergolong murah menjadi salah satu alasan banyak wisatawan juga tertarik untuk berkunjung sehingga tidak mengeluarkan biaya yang banyak (Gambar 11).

\section{Waktu Kunjung}




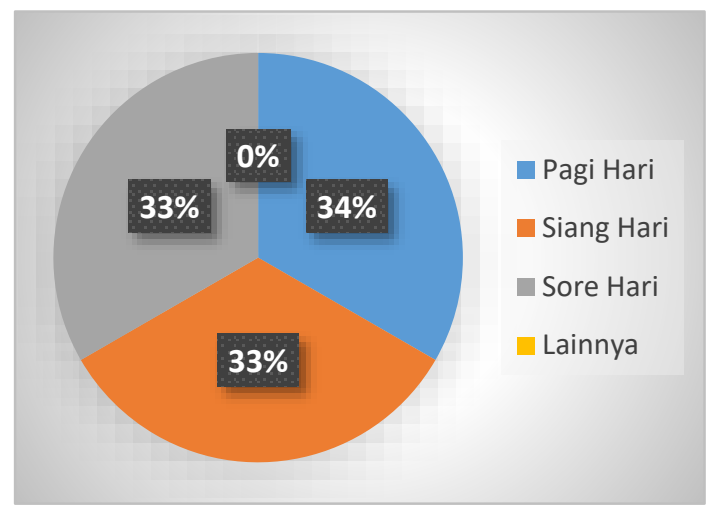

Gambar 12. Persentase Waktu Kunjung Pengunjung Gumuk Reco

Waktu kunjungan wisatawan obyek wisata Gumuk Reco yaitu pagi hari dengan persentase 34\%, presentase kedua dengan hasil imbang yaitu 33\% untuk pilihan waktu kunjung siang dan sore hari, memungkinkan untuk wisatawan yang berkunjung dihari kerja atau hari sekolah sehingga tidak dapat berkunjung pada pagi harinya (Gambar 12).

\section{Obyek Wisata Buatan Muncul Park Tinjauan Atraksi, Amenitas, Aksesibilitas}

Obyek wisata Muncul Park tersedia fasilitas yang mumupuni, wahana atau fasilitas utama yang bisa dinikmati adalah 2 kolam renang, dimana 1 kolam renang untuk anak-anak, dan 1 kolam renang untuk dewasa. Tersedia fasilitas pendukung di kolam renang seperti: seluncuran, ember tumpah, dan air mancur. Fasilitas umum yang tersedia diantaranya ialah: tempat parkir kendaraan, toilet/kamar mandi, gazebo, pedagang kaki lima. Harga tiket masuk yaitu Rp. 5.000,00 berlaku pada hari biasa dan Rp 7.500,00 berlaku pada hari libur. Obyek wisata Muncul Park terletak di dusun Rowoganjar, Desa Rowoboni, Kecamatan Banyubiru, Semarang, Jawa Tengah. Jalan yang lebarnya kurang lebih 6 meter pada jam-jam kantor sering mengakibatkan terjadinya kemacetan pada jalur ini, ada beberapa jalan yang masih rusak sehingga pengguna jalan harus ekstra hati-hati.

\section{Karakteristik Pengunjung Usia Pengunjung}

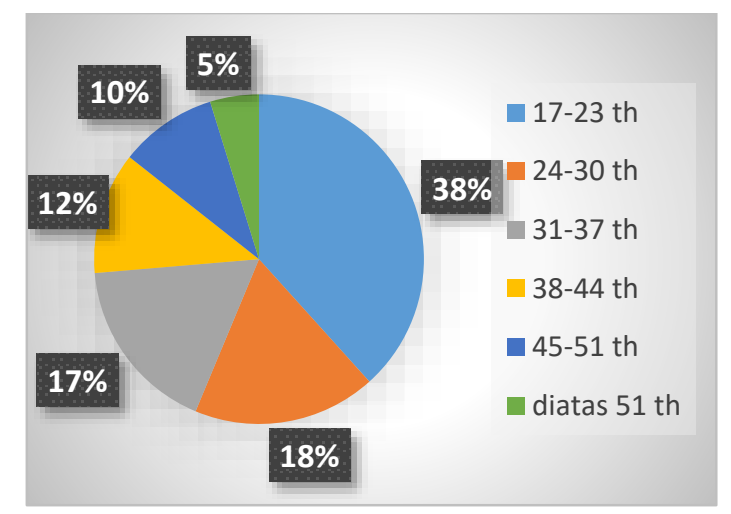

\section{Gambar 13. Persentase Usia Pengunjung Muncul Park}

Karakteristik pengunjung salah satunya di pengaruhi oleh faktor usia, rata-rata rentang usia pengunjung obyek wisata Muncul Park antara 17-23 tahun dengan persentase 38\% (Gambar 13), yaitu golongan remaja dan orang tua yang mengantar anaknya. Karena wahana ini merupakan destinasi wisata yang baru, maka antusiasme masyarakat tinggi untuk menikmati waktu berlibur di akhir pekan bersama keluarga maupun orang-orang terdekat. 


\section{Jenis Kelamin}

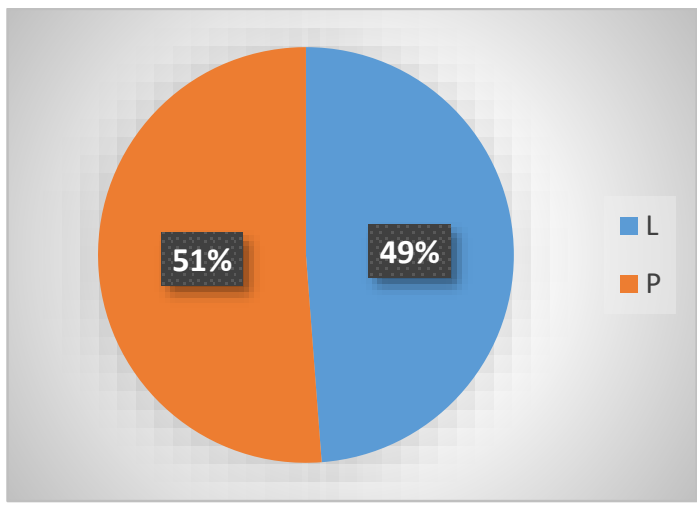

Gambar 14. Persentase Jenis Kelamin Pengunjung Muncul Park

Hasil observasi menunjukkan bahwa pengunjung obyek wisata muncul park banyak di dominasi dengan jenis kelamin perempuan dimana hasil penelitian menunjukkan persentase perempuan lebih besar yaitu $51 \%$ jika dibandingkan jenis kelamin laki-laki yang memiliki presentasi 49\% (Gambar 14).

\section{Pendidikan Terakhir}

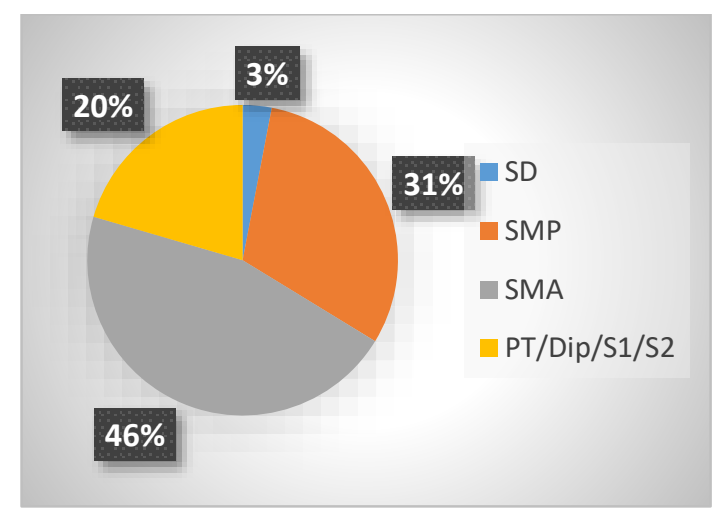

Gambar 15. Persentase Pendidikan Terakhir Pengunjung Muncul Park

Pendidikan terakhir menjadi faktor penentu kesejahteraan masyarakat, pendidikan terakhir pengunjung obyek wisata Muncul Park yang paling tinggi yaitu pada jenjang SMA dengan presentase $46 \%$. Presentase tinggi kedua yaitu $31 \%$ yaitu pada jenjang SMP. Pendidikan terakhir akan mempengaruhi oleh jenis pekerjaan pengunjung yang berada di obyek tersebut.

\section{Pekerjaan}




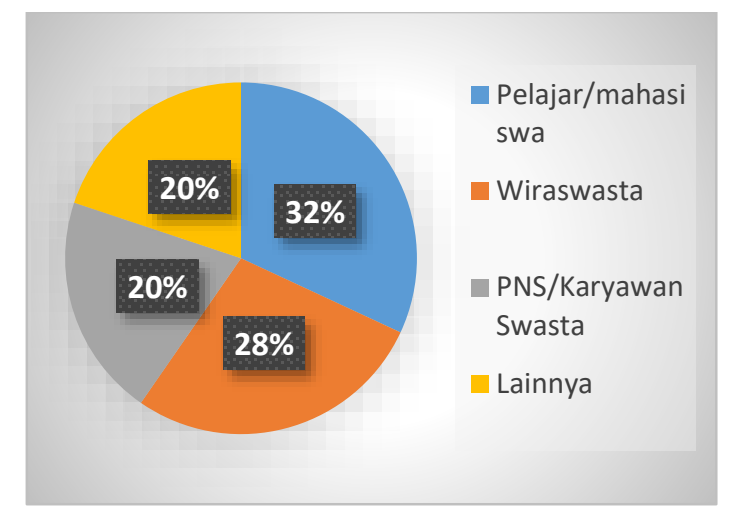

Gambar 16. Persentase Pekerjaan Pengunjung Muncul Park

Hasil penelitian menunjukkan bahwa pengunjung obyek wisata Muncul Park didominasi pelajar/mahasiswa dengan presentase 32\% karena kebanyakan para pengunjung mengantar adik ataupun saudaranya yang sedang menikmati wahana air di muncul park. Selain para pelajar juga ada para keluarga yang menghabiskan waktunya untuk anak-anaknya menikmati wahana air yang disediakan.

\section{Penghasilan}

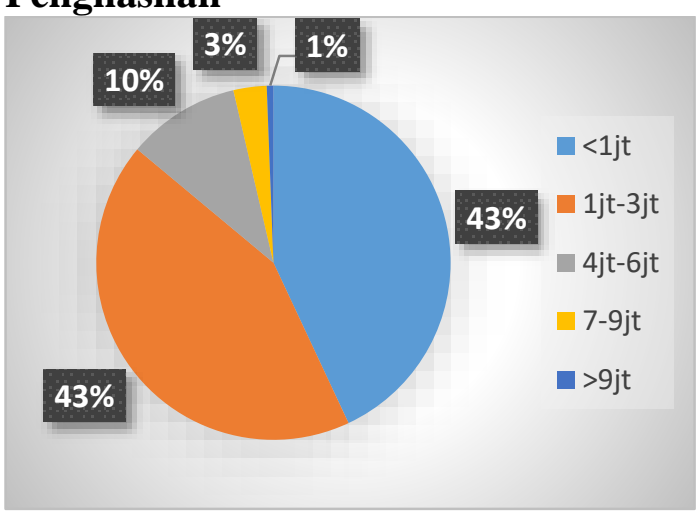

Gambar 17. Persentase Penghasilan Obyek Wisata Muncul Park

Hasil penelitian menunjukan penghasilan pengunjung yang mendominasi pada obyek wisata Muncul Park adalah kurang dari Rp 1.000.000,00. Hal ini sesuai dengan pekerjaan yang ada, dimana pelajar dan mahasiswa sebagai pengunjung dengan presentase terbanyak. Penghasilan yang ada juga menunjukan bahwa obyek wisata Muncul Park memiliki tiket retribusi murah sesuai dengan kantong pelajar.

\section{Waktu Kunjung}

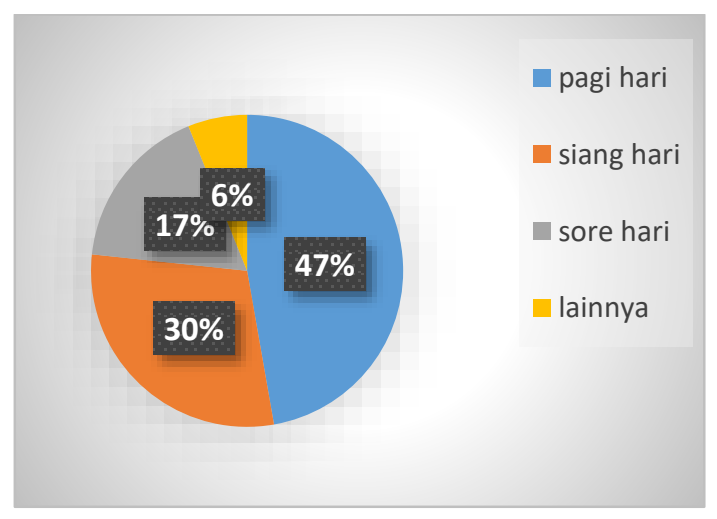




\section{Gambar 18. Persentase Waktu Kunjung Obyek Wisata Muncul Park}

Dari hasil penelitian rata-rata pengunjung datang ke muncul park pada waktu pagi hari yaitu 46\%, karena pagi hari udara yang masih segar dan belum panas jadi pilihan banyak pengunjung yang datang ke muncul park, pengunjung yang datang di hari-hari libur juga banyak sekali yang datang ketika pagi hari. Waktu kujung pilihan kedua yaitu pada siang hari dengan presentase $30 \%$ menjadi pilihan kedua ketika wisatawan datang dihari-hari kerja bukan di hari libur.

\section{Taman Kelinci}

\section{Tinjauan Atraksi, Amenitas, Aksesibilitas}

Taman Kelinci berada di Jalan Raya H. Toeyib Soebandi, Rowoboni, Banyubiru, Semarang. Taman Kelinci merupakan objek yang menawarkan perpaduan keindahan alami dan buatan manusia. Taman Kelinci merupakan perpaduan antara jenis wisata alam dan buatan, dapat dikatakan sebagai wisata alam karena taman kelinci memiliki daya tarik berupa sajian pemandangan alam yang indah berupa persawahan disekitarnya yang masih asri, sungai sebagai wahana outbond dan juga taman bunga yang merupakan unggulan Taman Kelinci. Wisata buatan di obyek tersebut adalah wisata kolam renang buatan, taman bermain, serta kandang kelinci sebagai ciri khas atau ikon taman kelinci. Peralatan yang ada mendukung kegiatan yang aman dan memenuhi standar seperti dalam permainan flyingfox, rafting, kolam renang anak yang memadai serta di sekitar sawah yang dilindungi oleh jaring - jaring.

Lokasi Taman Kelinci ini juga dekat dengan rumah makan, sehingga pengunjung dapat menikmati suguhan kuliner dan tak perlu jauh - jauh untuk mendapatkannya. Di dalam Taman Kelinci juga tersedia beberapa kantin - kantin yang menyediakan makanan, minuman serta oleh - oleh. Transportasi umum yang ada di obyek dibilang cukup baik karena terdapat angkutan pedesaan yang melewati jalan ini, namun wisatawan yang hadir biasanya membawa kendaraan pribadi seperti sepeda motor, mobil, ataupun bus pariwisata dibanding memakai kendaraan umum.

\section{Karakteristik Pengunjung}

\section{Usia Pengunjung}

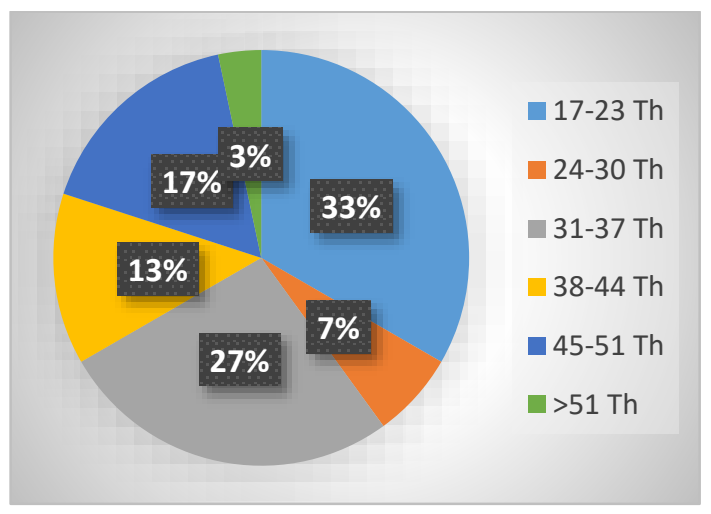

Gambar 19. Persentase Usia Pengunjung Taman Kelinci

Hasil penelitian menunjukan rata - rata usia pengunjung yang datang sebagai pendamping anak merupakan orang tua dengan umur Antara 17 - 23 tahun, di mana merupakan orang tua di usia muda dengan presentase 33\% (gambar 19). Obyek ini didominasi oleh anak kecil, sehingga orang tua mereka kebanyakan adalah orang tua muda, orang tua muda yang 
mengantar anak-anaknya berekreasi. Kehadiran wisata Taman Kelinci ini diharapkan memberikan pilihan wisata anak berbasis edukasi.

\section{Jenis Kelamin}

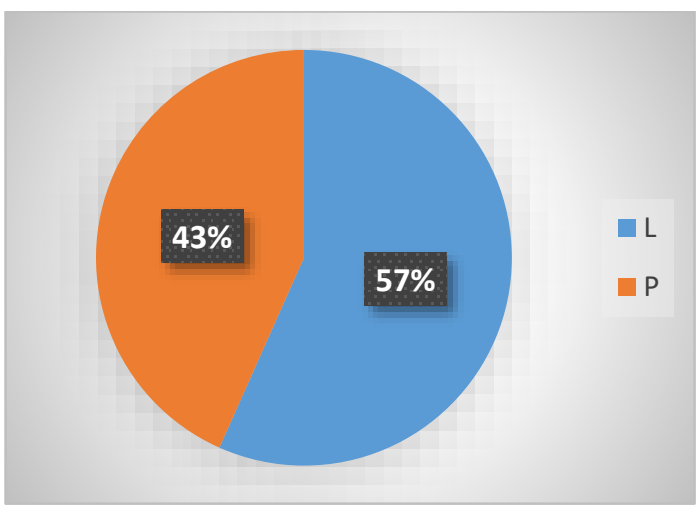

Gambar 20. Persentase Jenis Kelamin Pengunjung Taman Kelinci

Pengunjung Taman Kelinci didominasi oleh anak - anak karena memang wahana yang ada kebanyakan adalah wahana anak, di mana wisata ini berbasis edu - wisata. Anak dapat menggunakan kegiatan bermain sebagai sarana memecahkan persoalan intelektualnya. Pada penelitian ini, pengunjung obyek wisata Taman Kelinci didominasi oleh laki - laki, di mana presentase laki - laki adalah 57\% (Gambar 20). Hasil tersebut menunjukan perbandingan yang ada tidak begitu drastis, obyek penelitian dengan cakupan usia Antara 17 hingga diatas 51 tahun menunjukan pendampingan anak pada area wisata Taman Kelinci ini didominasi oleh pendamping laki - laki.

\section{Pendidikan Terakhir}

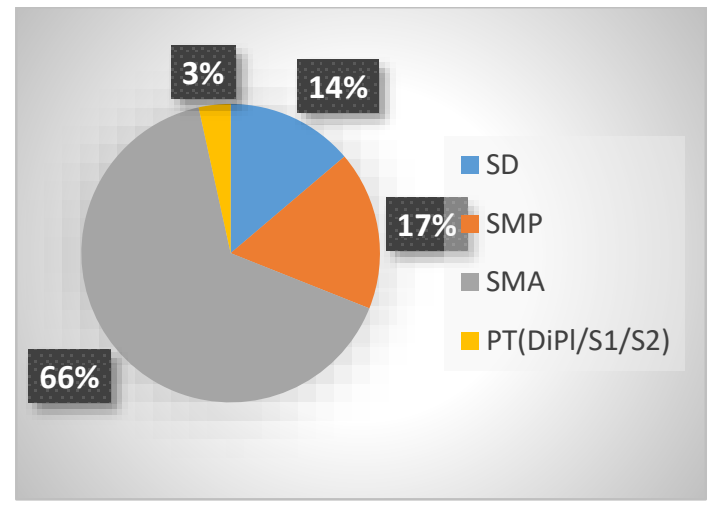

Gambar 21. Persentase Pendidikan Terakhir Pengunjung Taman Kelinci

Pendidikan terakhir para pendamping atau pengasuh yang ada pada obyek wisata Taman Kelinci yang paling tinggi adalah jenjang SMA dengan presentase sebanyak $66 \%$. Presentase tertinggi kedua yaitu SMP sebanyak 17\%, SD sebanyak 14\% dan PT 3\% (Gambar 21). Dari penelitian diketahui pengunjung yang hadir sebagai pendamping eduwisata anak di Taman Kelinci rata - rata berpendidikan terakhir di jenjang SMA (Gambar 21).

\section{Pekerjaan}




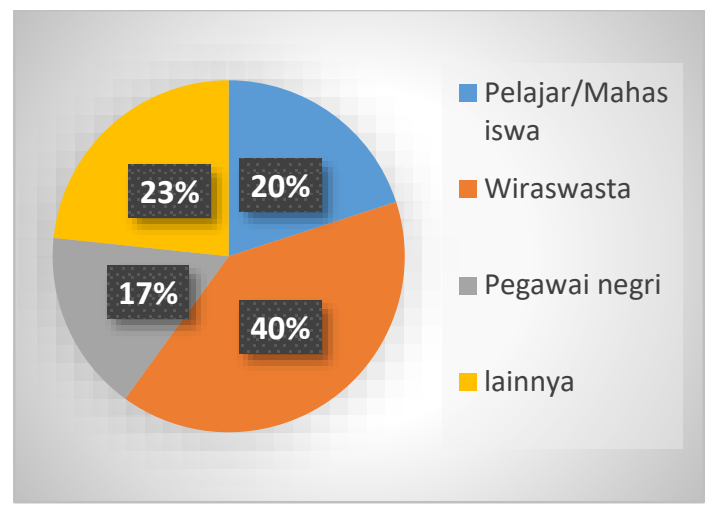

Gambar 22. Persentase Pekerjaan Pengunjung Taman Kelinci

Pekerjaan pengunjung, dalam hal ini pendamping anak yang ada di Taman Kelinci didominasi oleh wiraswasta dengan presentase $40 \%$ (Gambar 22). Selain itu, dengan presentase $23 \%$ adalah 'lainnya' yang didominasi ibu rumah tangga. Pekerjaan sebagai wiraswasta dan ibu rumah tangga memang memiliki keuntungan, dimana lebih fleksibel dalam hal waktu dibanding dengan pelajar/mahasiswa, ataupun pegawai negeri.

\section{Penghasilan}

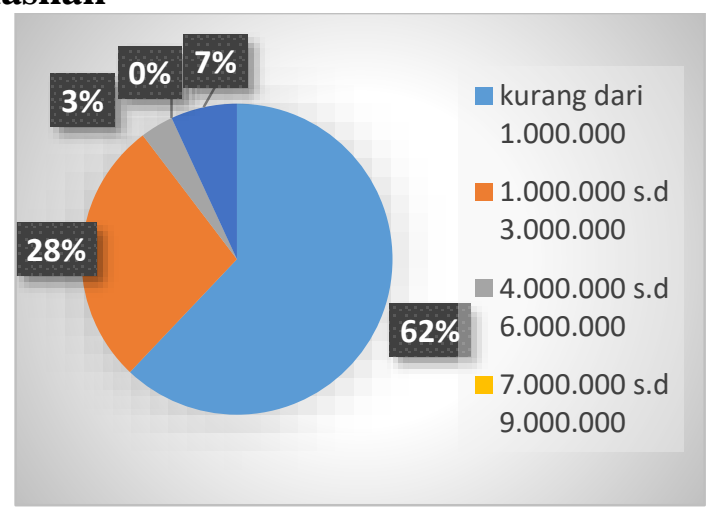

\section{Gambar 23. Persentase Waktu Kunjung Taman Kelinci}

Hasil penelitian menunjukan bahwa tingkat penghasilan yang mendominasi di Taman Kelinci adalah kurang dari Rp 1.000.000,00 hal ini berbanding lurus dengan pekerjaan yang dimiliki yaitu rata - rata sebagai wiraswasta dan ibu rumah tangga. Harga tiket masuk yang murah di Taman Kelinci tentu tidak membebani pengunjung yang berpenghasilan pas - pasan, dengan penghasilan yang ada, sehingga Taman Kelinci dianggap cocok untuk destinasi wisata edukasi anak mereka.

\section{Waktu Kunjung}

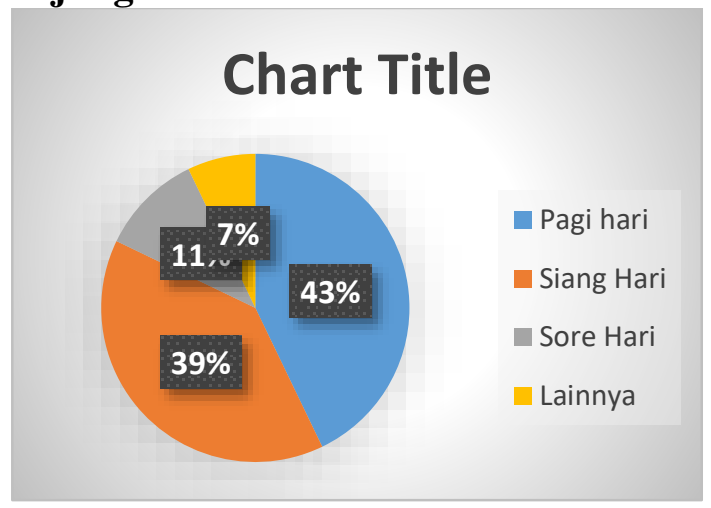




\section{Gambar 24. Persentase Waktu Kunjung Pengunjung Taman Kelinci}

Waktu kunjung yang dominan adalah pagi hari dengan presentase 43\% (Gambar 24). Pagi hari dianggap ideal sebagai waktu dalam mengunjungi wisata di Taman Kelinci, karena suasana alam yang ada masih terasa segar dan mendukung aktivitas edu-wisata berlangsung efekif dan anak - anak termotivasi untuk melakukan kegiatan - kegiatan positif. Kegiatan yang ada dalam hal ini adalah pembelajaran yang didapatkan dari wisata edukasi di Taman Kelinci.

\section{Kesimpulan}

Berdasarkan penelitian yang dilakukan pada obyek wisata kawasan Rawa Pening diketahui dua jenis obyek wisata yang ada, baik alam maupun buatan, ke-6 karakteristik pengunjung berkaitan erat dan berpengaruh terhadap penghasilan. Penghasilan juga merupakan salah satu hal yang berpengaruh terhadap alokasi uang untuk kebutuhan tersier. Kebutuhan tersier dalam hal ini menyangkut penggunaan penghasilan untuk kegiatan wisata. Faktor pendidikan juga menjadi pendukung dalam melakukan kegiatan wisata. Wisatawan yang mendominasi obyek wisata kawasan Rawa Pening adalah mereka yang duduk di bangku SMA, dimana pada usia ini merupakan usia - usia gemar mencoba hal - hal baru seperti mengeksplorasi tempat - tempat wisata. Adanya perkembangan teknologi menjadi faktor pendukung yang berdampak besar terhadap obyek wisata yang ada. Penggunaan media sosial, terutama oleh kaum muda menjadi pendorong semakin dikenalnya obyek wisata, hal ini juga menjadi ajang promosi tersendiri bagi obyek wisata terkait. Pengaruh lain yakni waktu kunjung, waktu kunjung obyek wisata yang ada dipengaruhi oleh profesi pengunjung, profesi yang ada menjadi penentu waktu kunjung, dimana wisatawan cenderung menghabiskan waktu sesuai dengan jam longgar mereka. Jam - jam dimana dianggap fleksibel dan dapat dimanfaatkan sebagai pengobat kejenuhan kerja. Waktu yang dihabiskan, rata - rata adalah akhir pekan dengan dominasi waktu kunjung di pagi hari.

\section{Daftar Pustaka}

Abimanyu, Kentasa. 2016. “Analisis Pemanfaatan Sumber Daya Alam Danau Rawa Pening Kabupaten Semarang”. Skripsi. Fakultas Ilmu Sosial Universitas Negeri Semarang.

Angga, Helln. 2017. "Pengembangan Obyek dan Daya Tarik Wisata Alam Sebagai Daerah Tujuan Wisata Di Kabupaten Karanganyar”. Jurnal Sosiologi DILEMA, Vol. 32 No. $1,2017$.

Baskoro, Probo. 2016. "Pengelolaan Kawasan Ekowisata Berbasis Masyarakat Serta Implikasinya Terhadap Ketahanan Masyarakat Sukarara". JGG-Jurnal Green Growth dan Manajemen Lingkungan, Vol. 5 No. 2, Desember 2016.

Belachew, Beyene. 2016. "Review on Ecotourism Opportunities and the Challenges for Natural Resource Management in Ethiopia”. Journal of Tourism, Hospitality and Sports, Vol.21, 2016.

Damasdino, Fian. 2015. "Studi Karakteristik Wisatawan dan Upaya Pengembangan Produk Wisata Tematik Di Pantai Goa Cemara, Pantai Kuwaru, dan Pantai Pandansimo Baru Kabupaten Bantul”. Jurnal Media Wisata, Vol. 13 No. 2, November 2015.

Hartono, Muhammad. Dkk. 2015. "Pengaruh Karakteristik Obyek Wisata Terhadap Keputusan Berkunjung Para Pengunjung Klenteng Sam Poo Kong Dengan Profil Pengunjung Sebagai Variabel Modernisasi”. Fakultas Ilmu Sosial dan Ilmu Politik Univeristas Diponegoro Semarang. 
Heriza, Dewinta. 2018. "Analisis Perubahan Kualitas Perairan Danau Rawa Pening Periode 2013, 2015, 2017 Dengan Menggunakan Data Citra Landset 8 Multitemporal”. Jurnal Geodesi Undip, Vol. 7 No. 1, Januari 2018.

Nugroho, Dwi. 2012. "Penentuan Strategi Pengembangan Obyek Wisata Di Sekitar Rawa Pening Kabupaten Semarang Berdasarkan Tingkat Kepuasan Pengunjung”. Skripsi. Semarang Fakultas Teknik Universitas Diponegoro Semarang.

Prasetyo, Aji. 2016. "Faktor-faktor yang Mempengaruhi Keputusan WIsatawan Dalam Berkunjung Ke Obyek Wisata Waduk Gajah Mungkur Wonogiri”. Skripsi. Surakarta Fakultas Keguruan dan Ilmu Pendidikan Universitas Sebelas Maret Surakarta.

Prihandoko, Adhip. 2008. "Analisis Potensi Obyek Wisata di Kabupaten Semarang”. Skripsi. Surakarta Fakultas Geografi Universitas Muhammadiyah Surakarta.

Priyanti, Agatha. Dkk. 2018. "Evaluasi Status Mutu Danau Rawapening”. Jurnal Pengelolaan Sumberdaya dan Lingkungan, Vol. 8 No. 2, Agustus 2018.

Rukti, Dhayita. 2014. "Potensi Pengembangan Ekowisata Berbasis Masyarakat Di Kawasan Rawapening, Kabupaten Semarang”. Jurnal Teknik PWK, Vol. 3 No. 1, Fakultas Teknik Universitas Diponegoro Semarang.

Samura, Oiyanti. 2017. "Perancangan Media Promosi Pariwisata untuk Daya Tarik Wisata Pemandian Muncul Banyubiru Kabupaten Semarang”. Skripsi. Salatiga Fakultas Teknologi Informasi Universitas Kristen Satya Wacana Salatiga.

Saputra, Dian. 2017. "Profil Pengunjung Obyek Wisata Pemandian Muncul Kabupaten Semarang”. Skripsi.. Semarang Fakultas Ekonomi dan Bisnis Universitas Diponegoro Semarang.

Sari, Suzanna Ratih. 2011. "Tourism Development in The Coastal Island of Guimaras Philippines". Journal Of Coastal development. Vol 4, No 3 (2001).

Seftyono, Cahyo. 2014. "Rawa Pening Dalam Perspektif Politik Lingkungan: Sebuah Kajian Awal". Indonesian Journal of Conservation, Vol. 3 No. 1, Juni 2014.

Setiawan, Lucky. dkk. 2016. "Karakteristik dan Presepsi Wisatawan Terhadap Daya Tarik Wisata Pantai Kata Di Kota Pariaman, Sumatera Barat”. Jurnal Destinasi Wisata, Vol. 4 No. 1, Denpasar 2016.

Subanti, Sri. 2015. "Kontribusi Nilai Ekonomi Pengembangan Kawasan Rawa Pening Di Kabupaten Semarang”. Universitas Sebelas Maret. Surakata.

Susilowati, Indah. 2013. "Valuasi Ekonomi Sumberdaya Alam Rawa Pening dan Strategi Pelestariannya di Kabupaten Semarang". Diponegoro Journal Of Economics, Vol. 2 No. 2, 2013. 